\title{
Article \\ Effects of Nitrogen Forms and Application Rates on Nitrogen Uptake, Photosynthetic Characteristics and Yield of Double-Cropping Rice in South China
}

\author{
Huaiyuan Fu, Dandan Cui and Hong Shen * \\ College of Natural Resources and Environment, South China Agricultural University, Guangzhou 510642, China; \\ hyuanfu@126.com (H.F.); cuidan0627@163.com (D.C.) \\ * Correspondence: hshen@scau.edu.cn
}

check for updates

Citation: Fu, H.; Cui, D.; Shen, H. Effects of Nitrogen Forms and Application Rates on Nitrogen Uptake, Photosynthetic Characteristics and Yield of Double-Cropping Rice in South China. Agronomy 2021, 11, 158. https://doi.org/10.3390/agronomy 11010158

Received: 21 December 2020

Accepted: 13 January 2021

Published: 15 January 2021

Publisher's Note: MDPI stays neutral with regard to jurisdictional claims in published maps and institutional affiliations.

Copyright: (c) 2021 by the authors. Licensee MDPI, Basel, Switzerland. This article is an open access article distributed under the terms and conditions of the Creative Commons Attribution (CC BY) license (https:/ / creativecommons.org/licenses/by/ $4.0 /)$.

\begin{abstract}
Nitrogen is an important element that affects the growth and yield of rice obviously. To explore the effects of nitrogen $(\mathrm{N})$ on the growth of double-cropping rice, four consecutive trials were conducted in South China Agricultural University. Four $\mathrm{N}$ forms and five $\mathrm{N}$ application rates were set up. Rice N uptake, leaf anatomic structure, leaf fluorescence parameters and yield were studied. The results showed that rice leaf SPAD value and $\mathrm{N}$ content with urea treatment were the highest among $4 \mathrm{~N}$ forms at the heading and flowering stage. The order of rice yield and $\mathrm{N}$ use efficiency treated with different $\mathrm{N}$ forms were urea $>$ ammonium sulfate $>$ ammonium nitrate $>$ sodium nitrate. The $\mathrm{N}$ application rate test showed that photochemical quantum efficiency and chemical quenching coefficient of rice leaves showed an inverted-V-type changing tendency with the highest value at $180 \mathrm{~kg} / \mathrm{hm}^{2} \mathrm{~N}$ treatment. Treatment with less than $180 \mathrm{~kg} / \mathrm{hm}^{2} \mathrm{~N}$ decreased the area and perimeter of small vascular bundles of the lateral leaves. Yield of early rice and later rice with $180 \mathrm{~kg} / \mathrm{hm}^{2}$ urea treatment was 17.42 to $33.28 \%$ and 6.17 to $21.28 \%$ higher than those of other $\mathrm{N}$ levels, respectively. The above results suggested that $180 \mathrm{~kg} / \mathrm{hm}^{2}$ of urea $\mathrm{N}$ are suitable and recommended for double-cropping rice planting in South China.
\end{abstract}

Keywords: rice; $\mathrm{n}$ application rate; $\mathrm{n}$ fertilizer forms; $\mathrm{n}$ utilization efficiency; photosynthetic characteristics

\section{Introduction}

Rice is the most important food crop in China, with a planting area of 31.857 million hectares. Most rice fields are distributed in the south of the Yangtze River [1]. South China locates in the tropical and subtropical regions, rich in water and heat resources. Rice can be planted several times in the area within one year [2]. To achieve better yield and quality, rice growers have applied large amounts of nitrogen $(\mathrm{N})$ fertilizer in different seasons of rice production. Excessive application of $\mathrm{N}$ fertilizer not only increased the probability of lodging and reduces the yield and quality of rice, but also leads to potential environmental risks $[3,4]$. At present, few studies have reported on $\mathrm{N}$ fertilizer incorporation technology for rice planting several times a year in South China. Previous studies on the amount of N application indicated that rice yield and the optimal amount of $\mathrm{N}$ application varied greatly depending on rice varieties, regional climate types and soil conditions [5,6]. The selection of suitable $\mathrm{N}$ fertilizer forms and $\mathrm{N}$ application rate was an important measure to improve the photosynthetic capacity and increase rice yield [7]. Rice preferentially takes up ammonium$\mathrm{N}$ rather than nitrate-N. On the basis of ammonium $\mathrm{N}$ fertilizer, an appropriate increase in nitrate $\mathrm{N}$ fertilizer can improve the $\mathrm{N}$ utilization efficiency of rice. In the total application of $\mathrm{N}$ fertilizer, adding $25 \%$ nitrate $\mathrm{N}$ could increase the tiller numbers and photosynthetic rate of rice seedlings by 35 and $24 \%$, respectively, and, thus, enhance the rice $\mathrm{N}$ utilization rate by $16-23 \%$ [8].

'Zeng Cheng Si Miao' (ZCSM) is one of the main cultivars of the rice-producing areas of South China and was listed as a national geographical indication protection product 
in 2004. The cultivar has a strong resistance to abiotic stress and was widely used in this area. However, studies on the effects of different $\mathrm{N}$ forms and amounts on the growth, development and yield of the cultivar have not been reported. In this paper, ZCSM was used, as materials, the effects of different $\mathrm{N}$ forms and dosages on rice $\mathrm{N}$ uptake, photosynthetic characteristics and yield were investigated during the key growth period of double-cropping rice plants, so as to explore an optimal nitrogen application model suitable for the production of double-cropping rice planting in South China.

\section{Materials and Methods}

\subsection{Experimental Conditions}

The experiment was performed in the greenhouse with plastic fill-roof and gauze walls at the College of Natural Resources and Environment, South China Agricultural University $\left(113^{\circ} 21^{\prime}\right.$ E, $23^{\circ} 9^{\prime}$ N), Guangzhou, P. R. China, from March 2019 to October 2020. The area belongs to a typical subtropical monsoon climate with annual average sunshine time $(1607 \mathrm{~h})$, annual average temperature $\left(21.9^{\circ} \mathrm{C}\right)$, an annual average rainfall $(1800.5$ $\mathrm{mm}$ ), annual rainy days (around 150 days) [9].

\subsection{Plant Materials and Treatments}

The tested strain was ZCSM cultivar, provided by Rice Research Institute of Guangdong Agricultural Academy of Sciences. The test soil was the paddy soil (typically sandy loam) sampled from the experimental base of South China Agricultural University. Then the soil was dried, crushed, mixed, and sieved prior to filling into the pots. The chemical properties of the soil were as follows: total $\mathrm{N}-0.939 \mathrm{~g} / \mathrm{kg}$, alkaline-hydrolytic N-93.60 $\mathrm{mg} / \mathrm{kg}$, available P-75.57 mg $/ \mathrm{kg}$, readily available K-160.34 mg $/ \mathrm{kg}, \mathrm{pH}-6.76$. The test pot is $25 \mathrm{~cm}$ high and $30 \mathrm{~cm}$ in diameter. Each pot is loaded with $10 \mathrm{~kg}$ soil.

In a different $\mathrm{N}$ form experiment, $\mathrm{N}$ forms included urea, ammonium sulfate $\left[\left(\mathrm{NH}_{4}\right)_{2} \mathrm{SO}_{4}\right]$, ammonium nitrate $\left(\mathrm{NH}_{4} \mathrm{NO}_{3}\right)$ and sodium nitrate $\left(\mathrm{NaNO}_{3}\right)$. Five treatments were set: N0 (without N), N1 (urea), N2 (ammonium sulfate), N3 (ammonium nitrate) and N4 (sodium nitrate). Pure $\mathrm{N}$ applied in each pot was $1.62 \mathrm{~g}$, equal to $180 \mathrm{~kg} / \mathrm{hm}^{2}$. In order to ensure the stability of $\mathrm{N}$ fertilizer, $5 \%$ nitrogenous nitrification inhibitor dicyandiamide was added in all treatments. In a different $\mathrm{N}$ levels experiment, urea (containing $46 \%$ pure $\mathrm{N}$ ) was applied at 5 levels: N0 (without N), N90 (1.76 g/pot, equal to $\left.90 \mathrm{~kg} / \mathrm{hm}^{2}\right), \mathrm{N} 180(3.52 \mathrm{~g} /$ pot, equal to $\left.180 \mathrm{~kg} / \mathrm{hm}^{2}\right), \mathrm{N} 270\left(5.28 \mathrm{~g} /\right.$ pot, equal to $\left.270 \mathrm{~kg} / \mathrm{hm}^{2}\right)$ and N360 $(7.04 \mathrm{~g} / \mathrm{pot}$, equal to 360 $\mathrm{kg} / \mathrm{hm}^{2}$ ). Eighteen pots were planted in the above treatments.

The early rice was sown on 27 March, transplanted on 26 April, and harvested on 15 July 2019. The late rice was sown on 27 June, transplanted on 28 July and harvested on 17 October 2019. Early rice was sown on $28 \mathrm{March}$, transplanted on 26 April and harvested on 17 July 2020. Late rice was sown on 29 June, transplanted on 28 July and harvested on 22 October 2020. The rice seedlings were grown in a greenhouse. The temperatures ranged from 20 to $34{ }^{\circ} \mathrm{C}$, and the relative humidity of 65 to $85 \%$ were kept during the rice growth periods. The total amount of $\mathrm{N}$ fertilizer applied is divided into base fertilizer, tiller fertilizer and spike fertilizer at the ratio of 4:4:2.

For each treatment in the experiment, calcium superphosphate $(6.75 \mathrm{~g} / \mathrm{pot}$, equal to $90 \mathrm{~kg} / \mathrm{hm}^{2}$ ) and potassium chloride [1.58 g/pot, equal to $105 \mathrm{~kg} / \mathrm{hm}^{2}$, base fertilizer $(0.79 \mathrm{~g})$ and spike fertilizer $(0.79 \mathrm{~g})]$ were applied before transplanting. Rice seedlings were raised using the conventional method, with 3 holes per pot and 1 plant for each hole. The management of diseases, pests and weeds is carried out in accordance with the local conventional methods for the prevention and control of rice diseases and pests. Rice diseases and pests including rice blast, striped rice borer, etc., were dealt with using pesticides on the market. Weeds were cut artificially.

\subsection{Determination of Rice Dry Weight and N Uptake}

Samples were collected during the rice tillering stage (extensive tillering stage), jointing and booting stage (stem elongation and booting), heading and flowering stage (flow- 
ering, anthesis; development of fruit) and the mature stage (ripening), respectively [10]. Rice leaves, stems and spike were split and dried $\left(120^{\circ} \mathrm{C}\right.$ for half an hour, then dry at $65^{\circ} \mathrm{C}$ to constant weight), then measured by an electronic balance with a precision of $0.1 \mathrm{mg}$, ground and sieved, and then digested with sulfuric acid and hydrogen peroxide. The sample was determined using the micro-Kjeldahl method with an auto-Kjeldahl analyzer (Hanon K1100, Shanghai, China) for total N.

The calculation formula of nitrogen use efficiency (NUE) is as follows [11]:

$$
\begin{gathered}
\mathrm{NUP}=\mathrm{DW} \times \mathrm{NC} \\
\mathrm{NUE}=\frac{\mathrm{NUP}_{\text {with N }}-\mathrm{NUP}_{\text {without } \mathrm{N}}}{\mathrm{PN}} \times 100 \%
\end{gathered}
$$

In the formulae, "NUP" means N uptake by plants. "NUP with N" or "NUP without $\mathrm{N}^{\prime \prime}$ represents $\mathrm{N}$ uptake by plants treated with or without $\mathrm{N}$ application, respectively. "DW" means dry weight of plants. "NC" means $\mathrm{N}$ content of plant. "NUE" means nitrogen use efficiency. "PN" means pure $\mathrm{N}$ application rate.

\subsection{Determination of SPAD Value}

Soil and plant analyzer development (SPAD) value of the top leaf of rice was measured by a chlorophyll meter (SPAD-502 Plus, Konica Minolta, Tokyo, Japan) at the key growth period of rice seedlings (the rice tillering stage, jointing and booting stage, heading and flowering stage and the mature stage) [12].

\subsection{Observation of Leaf Anatomy Section}

During the heading and flowering period, the middle leaf segments of the top leaf of rice were selected for paraffin sectioning with the steps of fixation, embedding, sectioning, staining, decolorization, and sealing wax. The method refers to the paraffin plant tissue section method [13]. The slices were observed under the $20 \times$ and $40 \times$ optical microscopes, and the slices with clear texture were selected and photographed. The numbers of small vascular bundles, perimeter, area and alveolar cell area of the lateral leaves of rice leaves were calculated by Image J software (National Institutes of Mental Health, USA).

\subsection{Determination of Fluorescence Parameters}

During the key growth period of rice seedlings, the chlorophyll fluorescence imaging system (IMAGING-PAM, WALZ, Salzkotten, Germany) was used to measure the chlorophyll fluorescence parameters of leaves including photochemical quantum efficiency $\left(\mathrm{F}_{\mathrm{v}} / \mathrm{F}_{\mathrm{m}}\right)$, photochemical quenching coefficient $\left(\mathrm{q}_{\mathrm{P}}\right)$ and non-photochemical quenching coefficient $\left(\mathrm{q}_{\mathrm{N}}\right)$.

\subsection{Rice Yield Measurement}

After the rice plants matured completely, rice plants were harvested. The stems, leaves, panicles and other parts were collected separately and dried at $75^{\circ} \mathrm{C}$ and weighted, respectively.

\subsection{Statistical Analysis}

The results were expressed as mean \pm standard deviation (SD). One-way ANOVA was applied to check the mean and statistical significance amongst the values obtained with Duncan's multiple range tests at confidence interval 95\%. SPSS 25.0 version (Chicago, IL, USA) was used for data analyses.

\section{Results and Discussion}

\subsection{Effects of N Forms on Leaf SPAD Value and N Content of Rice Seedlings}

In this study, the effects of different $\mathrm{N}$ forms on the SPAD value and leaf $\mathrm{N}$ content were investigated (Figure 1). The results indicated that the SPAD value of the top leaf of rice showed a gradual upward trend from the tillering stage to the jointing-booting stage, and a 
downward trend from the heading-flowering stage to the maturity stage. SPAD value of rice leaves treated with $\mathrm{N} 3$ at the tillering stage was the highest, which was increased by 6.68 to $15.29 \%$ compared with other treatments. It might be that a moderate $\mathrm{NH}_{4}-\mathrm{N}$ and $\mathrm{NO}_{3}-\mathrm{N}$ mixed nutrient ratio could make the physiological function of rice in the early stage handle the optimal equilibrium state, thereby improving the photosynthetic performance of rice leaves. Chen et al.'s research results also support this point of view [14]. The order of leaf SPAD value of different treatments at jointing-booting stage and heading-flowering stage was $\mathrm{N} 1>\mathrm{N} 2>\mathrm{N} 3>\mathrm{N} 4>\mathrm{N} 0$, and SPAD value of N1 treatment was 2.60 to $28.47 \%$ higher than those of other treatments. Leaf SPAD value of N1, N2 and N3 treatments during the whole growth periods were significantly higher than that of $\mathrm{N} 4$ treatment, indicating that only NO3-N fertilizer was not suitable for the photosynthesis of rice leaves.

(a)

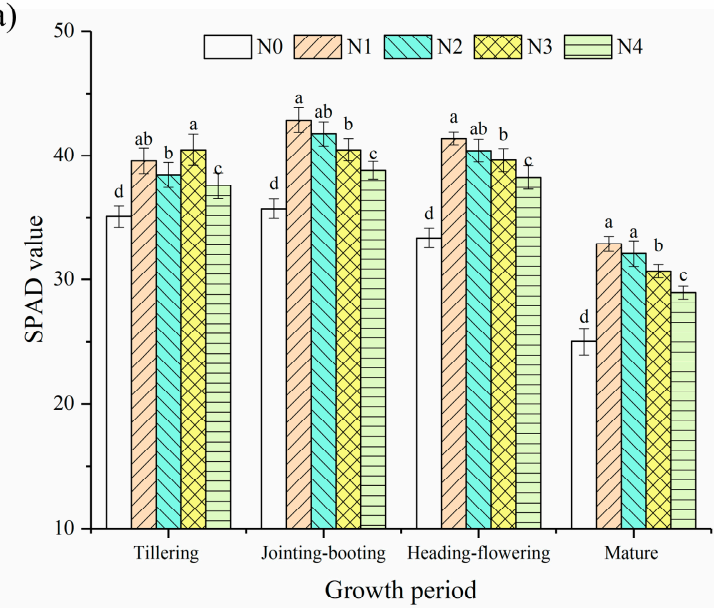

(b)

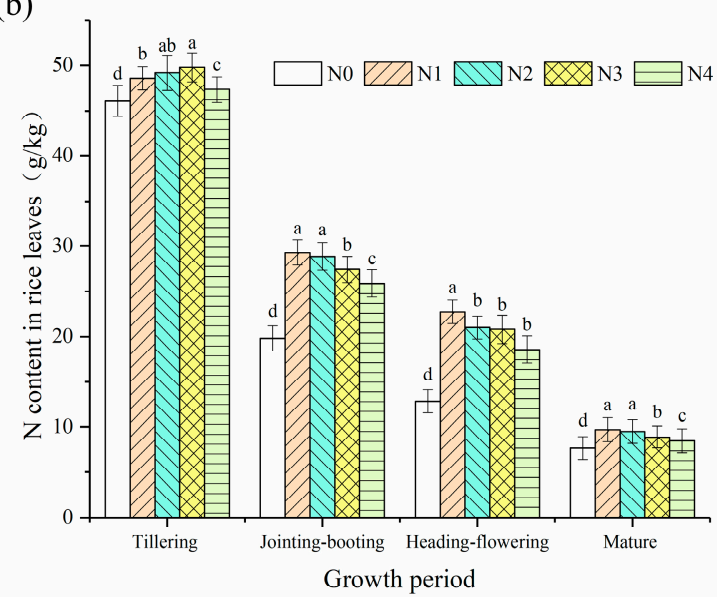

Figure 1. Effect of $\mathrm{N}$ forms on soil and plant analyzer development (SPAD) value and leaf $\mathrm{N}$ content of rice seedings. (a) SPAD value of rice leaf and (b) $\mathrm{N}$ content of rice leaves. Vertical bars indicated the standard error. Different letters with the same growth period indicated significant differences at $p<0.05$ according to the Duncan's test. Tillering means tillering stage; jointing-booting means jointing-booting stage; heading-flowering means heading-flowering stage; mature means mature stage.

Results from Figure $1 \mathrm{~b}$ indicated that $\mathrm{N}$ fertilizer forms significantly influenced leaf $\mathrm{N}$ uptake of double-cropping rice plants. Li and Shi (2007) found that the order of $\mathrm{N}$ uptake treated with different $\mathrm{N}$ forms at the tillering stage was ammonium nitrate $>$ ammonium $\mathrm{N}$ (ammonium sulfate) $>$ nitrate $\mathrm{N}$ (potassium nitrate) [15]. Our results supported the above view. The order of $\mathrm{N}$ content in rice leaves treated with different $\mathrm{N}$ forms was $\mathrm{N} 3$ (ammonium nitrate) $>\mathrm{N} 2$ (ammonium sulfate) $>\mathrm{N} 1$ (urea) $>\mathrm{N} 4$ ( (sodium nitrate) $>$ N0 (without $\mathrm{N}$ ) during the tillering period. In comparison to other treatments, leaf $\mathrm{N}$ content of N1 (urea treatment) was increased by 8.23 to $22.20 \%$ at the heading and flowering stages.

\subsection{Effects of $N$ Forms on N Use Efficiency and Yield of Double-Cropping Rice}

The effects of different $\mathrm{N}$ form treatments on $\mathrm{N}$ use efficiency (NUE), yield and components of double-cropping rice were shown in Table 1. The results showed that NUE of late rice was significantly higher than that of early rice (Table 1). Under different $\mathrm{N}$ form treatments, the NUE of double-cropping rice treated with urea was $44.08 \%$, which was the highest among four treatments. However, the NUE of N4 (sodium nitrate) was the lowest, with an average of $37.39 \%$. The yield of double-cropping rice (early rice plus later rice) treated with $\mathrm{N} 1$ (urea) was the highest, with an average of $18.01 \mathrm{~g} /$ pot. The yields of early rice plus later rice were 8.28 to $38.15 \%$ and 8.81 to $27.81 \%$ higher than other $\mathrm{N}$ treatments, respectively. Furthermore, the order of different $\mathrm{N}$ forms on effective panicles of double-cropping rice plants were N1 $>$ N2 $>$ N3 $>$ N4 $>$ N0. Treatments with N1 (urea) or $\mathrm{N} 2$ (ammonium sulfate) were more conducive to the growth and development of doublecropping rice and, thus, increased rice yield. Noteworthy, later rice had a higher grain yield 
than early rice (Table 1 ). The reason might be that the temperature and the activity of urease was higher during the growth of later rice than those during the growth of early rice [16]. Chen et al. found that the application of fertilizers could significantly stimulate soil urease activity, enhance urea hydrolysis and release a large amount of NH4+. The process would contribute to rice $\mathrm{N}$ uptake [17].

Table 1. Effects of $\mathrm{N}$ forms on $\mathrm{N}$ use efficiency (NUE) and yield of double-cropping rice.

\begin{tabular}{|c|c|c|c|c|c|c|c|}
\hline Year & Rice & Treatment & $\begin{array}{c}\text { Efficient Panicle } \\
\text { Per Plant }\end{array}$ & $\begin{array}{c}\text { Setting } \\
\text { Percentage (\%) }\end{array}$ & $\begin{array}{c}\text { Thousand Seed } \\
\text { Weight (g) }\end{array}$ & $\begin{array}{l}\text { Yield } \\
\text { (g/pot) }\end{array}$ & $\begin{array}{c}\text { NUE } \\
(\%)\end{array}$ \\
\hline \multirow{10}{*}{2019} & \multirow{5}{*}{ Early rice } & No & $4.0 \pm 0.0 \mathrm{c}$ & $80.5 \pm 0.7 b$ & $16.0 \pm 0.8 \mathrm{~b}$ & $6.9 \pm 0.5 \mathrm{e}$ & - \\
\hline & & N1 & $7.7 \pm 0.6 \mathrm{a}$ & $83.0 \pm 0.8 \mathrm{a}$ & $17.2 \pm 0.4 \mathrm{ab}$ & $17.1 \pm 0.4 \mathrm{a}$ & 43.62 \\
\hline & & N2 & $7.3 \pm 0.6 \mathrm{a}$ & $83.5 \pm 0.8 \mathrm{a}$ & $17.4 \pm 0.8 \mathrm{a}$ & $15.8 \pm 0.2 b$ & 42.42 \\
\hline & & N3 & $7.0 \pm 0.0 \mathrm{a}$ & $82.7 \pm 1.1 \mathrm{a}$ & $17.5 \pm 0.6 \mathrm{a}$ & $14.0 \pm 0.8 c$ & 41.02 \\
\hline & & $\mathrm{N} 4$ & $6.0 \pm 0.0 \mathrm{~b}$ & $80.3 \pm 0.5 b$ & $17.0 \pm 0.5 \mathrm{ab}$ & $12.4 \pm 0.3 \mathrm{~d}$ & 37.23 \\
\hline & \multirow{5}{*}{ Late rice } & N0 & $5.0 \pm 0.0 \mathrm{~d}$ & $81.3 \pm 0.3 c$ & $16.2 \pm 0.6 \mathrm{~b}$ & $7.1 \pm 0.6 \mathrm{e}$ & - \\
\hline & & N1 & $8.3 \pm 0.6 \mathrm{a}$ & $84.0 \pm 0.3 \mathrm{a}$ & $17.8 \pm 0.8 \mathrm{a}$ & $18.9 \pm 0.8 \mathrm{a}$ & 44.53 \\
\hline & & $\mathrm{N} 2$ & $7.7 \pm 0.6 \mathrm{ab}$ & $82.9 \pm 0.7 \mathrm{ab}$ & $17.7 \pm 0.4 \mathrm{a}$ & $17.4 \pm 0.3 \mathrm{~b}$ & 43.27 \\
\hline & & N3 & $7.3 \pm 0.6 b c$ & $82.4 \pm 1.3 \mathrm{bc}$ & $17.8 \pm 0.3 \mathrm{a}$ & $16.1 \pm 0.3 c$ & 41.63 \\
\hline & & $\mathrm{N} 4$ & $6.7 \pm 0.6 c$ & $81.1 \pm 0.7 c$ & $17.2 \pm 0.4 \mathrm{a}$ & $14.8 \pm 1.0 \mathrm{~d}$ & 37.54 \\
\hline
\end{tabular}

Values followed by a different lower-case letter in the same vertical column were statistically different ( $p<0.05 ;$ Duncan's test). Early rice and late rice were compared separately.

\subsection{Effects of N Application Rates on Fluorescence Parameters and SPAD Value of Rice Leaves}

PSII is the location where photosynthesis of plants is initially affected by inhibition. Chlorophyll fluorescence technology is regarded as an internal probe of the relationship between plant photosynthesis and environment. Changes in chlorophyll fluorescence parameters can reflect the impacts of environmental conditions on plant growth to a certain extent [18]. $F_{\mathrm{v}} / \mathrm{F}_{\mathrm{m}}$ is the largest (potential) photochemical quantum efficiency of the PSII reaction center, which could characterize the light energy utilization and conversion rate of the original reaction center [19]. As showed in Figure 2a, as the growth period progressed, the $F_{v} / F_{m}$ at the jointing and booting stage gradually increased and reached the peak at the heading and flowering stage. The $\mathrm{F}_{\mathrm{v}} / \mathrm{F}_{\mathrm{m}}$ of rice leaves under different $\mathrm{N}$ application rates increased firstly and then decreased, showing an inverted $\mathrm{V}$-shaped changing trend as a whole. Compared with $\mathrm{N} 0$ treatment at the jointing booting stage, the $\mathrm{F}_{\mathrm{v}} / \mathrm{F}_{\mathrm{m}}$ values with $\mathrm{N} 90, \mathrm{~N} 180, \mathrm{~N} 270$, and N360 treatments were increased by 2.2, 5.6, 2.8 and 2.6\%, respectively. Compared with $\mathrm{N} 0$ treatment at the heading and flowering stage, the $\mathrm{F}_{\mathrm{v}} / \mathrm{F}_{\mathrm{m}}$ values of rice leaves treated with N90, N180, N270, and N360 were increased by 5.5, 9.7, 4.2 and 2.8\%, respectively. The $\mathrm{F}_{\mathrm{v}} / \mathrm{F}_{\mathrm{m}}$ value with $\mathrm{N} 180$ treatment was the highest (Figure $2 \mathrm{a}$ ). The above results suggested that an appropriate $\mathrm{N}$ application rate could promote the $\mathrm{F}_{\mathrm{v}} / \mathrm{F}_{\mathrm{m}}$ value of rice leaves obviously.

The photochemical quenching coefficient $\mathrm{q}_{\mathrm{P}}$ is used to describe the share of light energy absorbed by the PSII antenna pigment for photochemical electron transfer and reflects the openness of the PSII reaction center [20]. Through the analysis of $\mathrm{qP}_{\mathrm{P}}$ in four growth stages of rice under different $\mathrm{N}$ application rates, it was noteworthy that the $\mathrm{qP}_{\mathrm{P}}$ performance trend is similar to that of $F_{v} / F_{m}$ (Figure $2 b$ ). With the advancement of rice growth and development, $\mathrm{q}_{\mathrm{P}}$ values rose firstly and then fell, reaching the peaking value at the flowering stage. In comparison to N0 treatment, the qP value of $\mathrm{N}$ application at heading and flowering stage was increased by 7.21 to $11.44 \%$. However, the qP value of N360 treatment was 3.02\% lower than that of N180 treatment, and N180 treatment had the highest qP value. The results indicated that $\mathrm{N}$ application was beneficial to the opening of PSII reaction centers of rice leaves at heading and flowering stage, which enhanced the electron flow from the PSII oxidation side to the PSII reaction center, but excessive N application would reduce the opening degree and inhibit the electron transfer process. 
(a)

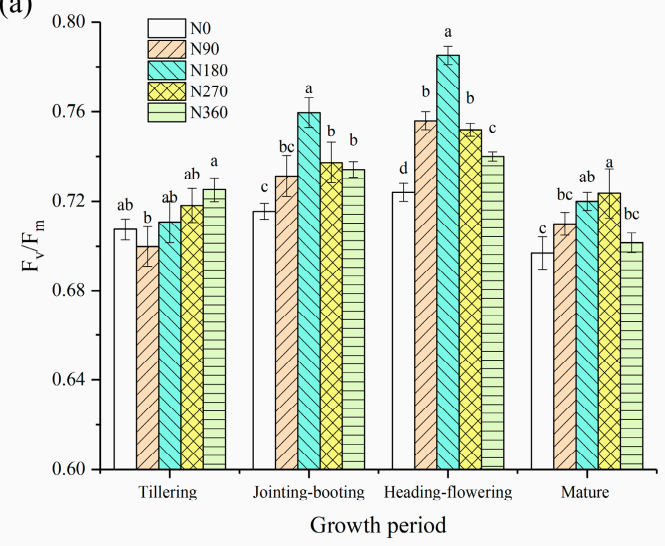

(c)

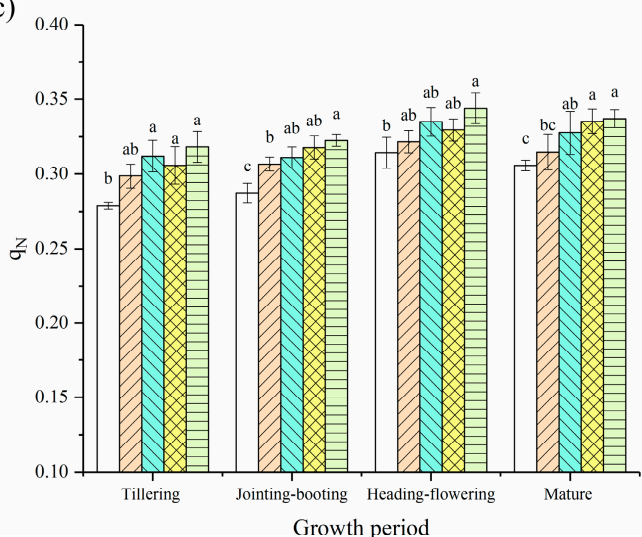

(b)

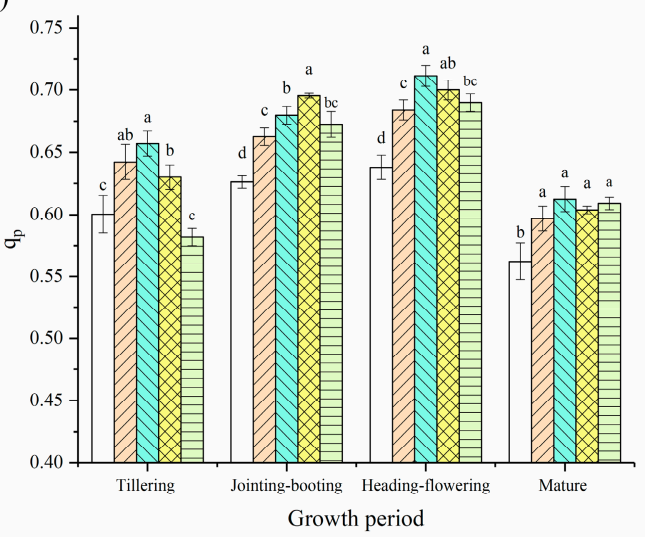

(d)

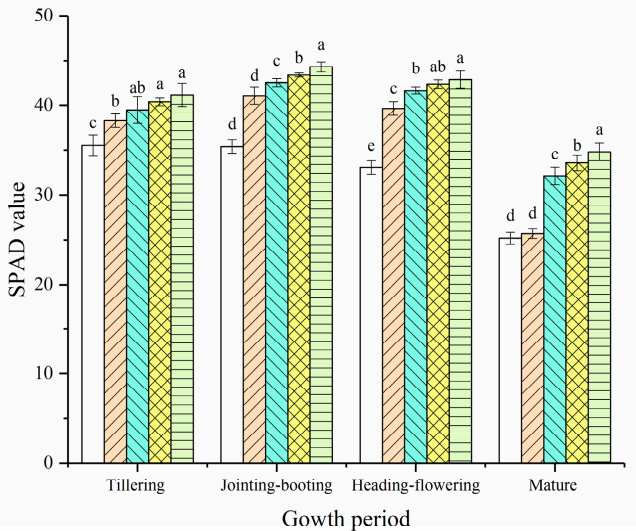

Figure 2. Effects of $N$ application rates on fluorescence parameters and SPAD value of rice leaves. (a) $F_{v} / F_{m}$ value; (b) $q_{P}$ value; (c) qN value; (d) SPAD value. Vertical bars indicated the standard error. Different letters with the same growth period indicated significant differences at $p<0.05$ according to the Duncan's test. Tillering means tillering stage; jointing-booting means jointing-booting stage; heading-flowering means heading-flowering stage; mature means mature stage.

The non-photochemical quenching coefficient $\mathrm{q}_{\mathrm{N}}$ reflects the ability of plants to dissipate excess light energy in the form of heat and is the self-protection mechanism of the photosynthetic system [21]. As shown in Figure 2c, the $q_{N}$ value among different growth stages did not vary greatly, and no significant differences were observed among different $\mathrm{N}$ treatments. However, the overall $\mathrm{q}_{\mathrm{N}}$ values with N180, N270 and N360 treatments during the whole growth period were higher than those of N0 and N90 treatments. The results showed that the heat dissipation capacity of the light energy of the PSII reaction center of the rice leaf PSII treated with the middle and high N dosages (180 to $360 \mathrm{~kg} / \mathrm{hm}^{2} \mathrm{~N}$ ) was stronger than that of the low $\mathrm{N}$ dosages $\left(0\right.$ to $\left.90 \mathrm{~kg} / \mathrm{hm}^{2} \mathrm{~N}\right)$ during the whole growth period of rice seedlings. Consistent with our results, Zhang et al. pointed out that a proper amount of $\mathrm{N}$ application rate (160 to $200 \mathrm{~kg} / \mathrm{hm}^{2}$ ) could help improve the conversion efficiency of primary light energy in the PSII reaction center of rice leaves, reduce the activity inhibition of the electron transfer efficiency of the PSII reaction center and enhance the PSII oxidation lateral PSII reaction [22].

SPAD chlorophyll meter can indirectly reflect the $\mathrm{N}$ nutrition status of plants by measuring the reflectance of multiple wave bands of leaves [23]. Results from Figure $2 \mathrm{~d}$ indicated that leaf SPAD values of all treatments were low at tillering stage and then increased gradually, reaching the maximum value at the heading and flowering stage, and then began to decrease. There were no significant differences of SPAD value among different $\mathrm{N}$ dosage treatments at tillering stage (Figure 2d). The amount of $\mathrm{N}$ applied at the jointing and booting stage had a significant effect on leaf SPAD value of rice seedlings. Compared with N0 treatment, leaf SPAD values treated with other $\mathrm{N}$ dosages showed significant differences. The order of SPAD values of different N treatments was N360 > 
N270 > N180 > N90 > N0. However, at the heading and flowering stage, no significant differences of SPAD value were not observed among N180, N270 and N360 treatments. Leaf SPAD value gradually decreased at the mature stage, and SPAD value treated with N270 and N360 showed higher values in comparison to N180 treatment. Excessive N application would lead to higher chlorophyll content in leaves, resulting in photo-oxidation metabolism and long-term impact on dry matter accumulation and NUE [24]. Appropriate amounts of $\mathrm{N}$ fertilizer can make the functional leaves of rice at heading and flowering stage to have more light capture ability and photochemical efficiency, improve the photosynthetic characteristics of flag leaves and promote rice yield [20].

\subsection{Effects of N Application Rates on Leaf Anatomical Structure}

The flag leaves and anatomical structures of rice treated with different $\mathrm{N}$ application rates at the heading and flowering stage were shown in Figure 3. It was observed that the color of rice leaves treated with N180, N270 and N360 was deeper and darker than those of N90 and N0 treatments; however, the difference in leaf color of N180, N270 and N360 treatments could not be distinguished by naked eyes. The volume of mesophyll cells in the leaves of N0 and N90 treatments was much smaller than that of N180, N270 and N360 treatments (Figure 3b), but no significant differences of the mesophyll cell volume were observed among N180, N270 and N360 treatments. The phenomenon might be the adaptive mechanism of rice leaves' response to $\mathrm{N}$ deficiency. Xiong et al. found that rice leaf mesophyll cells of low $\mathrm{N}$ treatments reduced in volume and increased in number, which was conducive to the scattering of light energy, thereby reducing the capture of light energy by chloroplasts and promoting $\mathrm{CO}_{2}$ transportation [25]. The volume and number of vascular bundles were positively correlated with plant leaf growth and photosynthetic rate [26]. The area and circumference of rice small vascular bundles, as well as the area and number of vesicle cells, were significantly reduced under adversity conditions [27].

In Table 2, the statistical results of leaf anatomy showed that the number of small vascular bundles treated with $\mathrm{N}$ application was more than that of N0 treatment, but there were no significant differences of small vascular bundles among different $\mathrm{N}$ dosage treatments. The area and perimeter of small vascular bundles increased with the increase in $\mathrm{N}$ application rate. Compared with $\mathrm{N} 0$ treatment, the area and circumference of small vascular bundles treated with N180 were increased by 20.86 and $12.73 \%$, respectively; the area and circumference of small vascular bundles treated with N360 increased by 22.09 and $9.14 \%$ in comparison to N180 treatment. In addition, within the range of 0 to $180 \mathrm{~kg} / \mathrm{hm}^{2}$ $\mathrm{N}$ application, the area of vesicle cells in the lateral leaves of rice seedlings increased with the increase in $\mathrm{N}$ application rate. Compared with N0 treatment, the area of vesicle cells of N180 treatment was increased by $26.85 \%$. However, the area of vesicle cells tended to decrease when treated with 270 and $360 \mathrm{~kg} / \mathrm{hm}^{2} \mathrm{~N}$ application. The results indicate that low $\mathrm{N}$ treatment limited the development of small vascular bundles, resulting in smaller vesicle cells, which would inhibit photosynthesis and nutrient transport capacity of rice seedlings, resulting in the decrease in rice yields. 
(a) Rice leaf
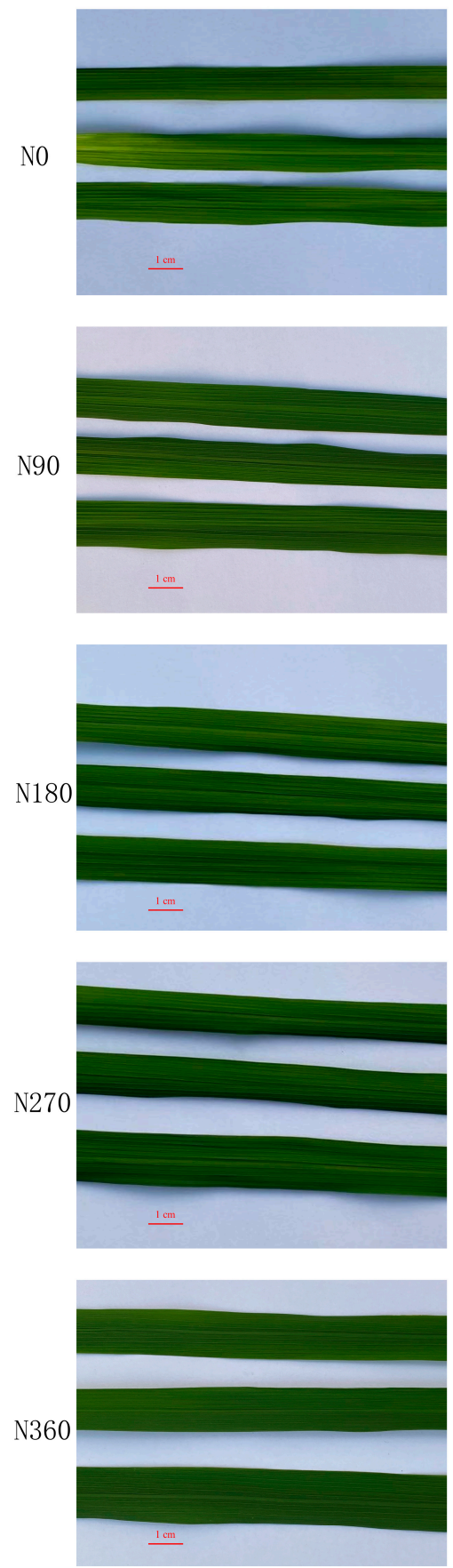

(b) Paraffin section of leaf (20X)
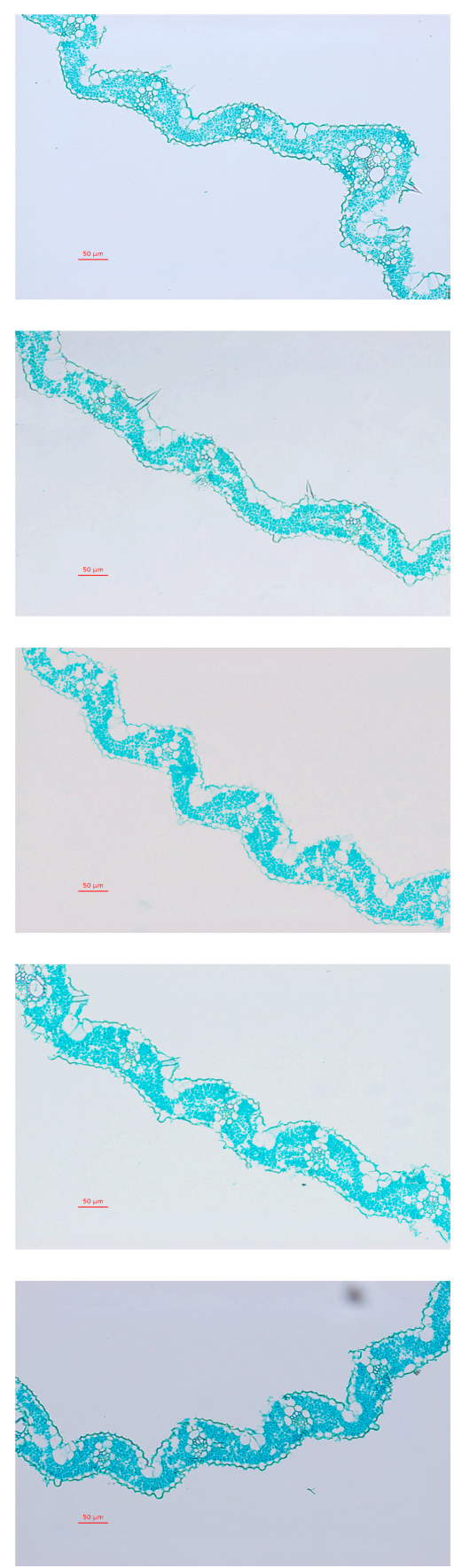

(c) Paraffin section of leaf (40X)
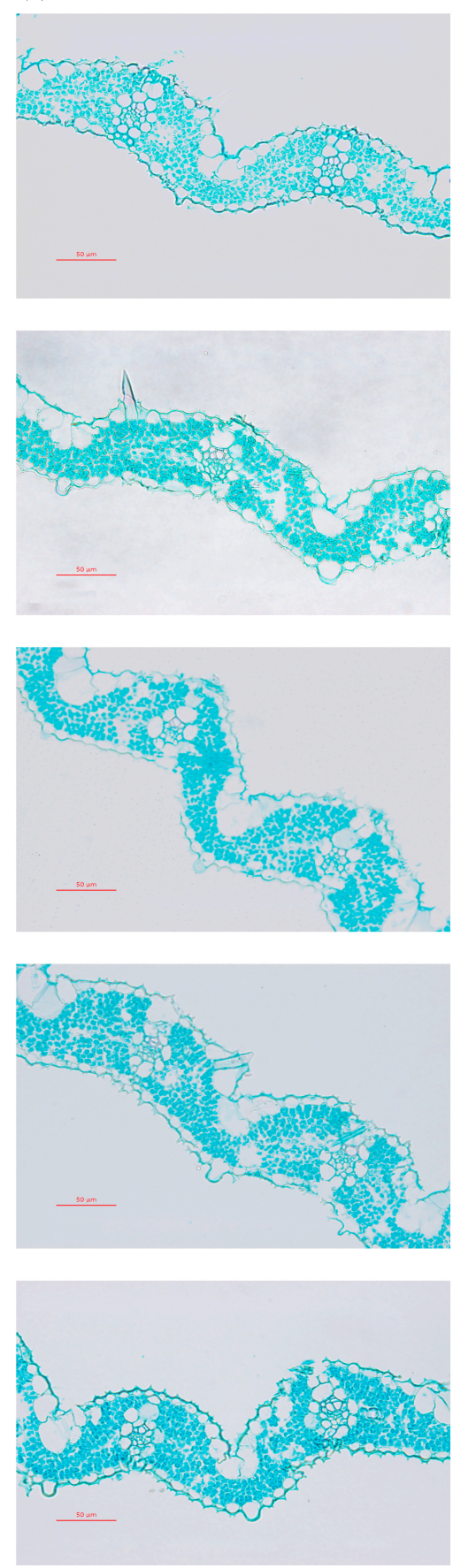

Figure 3. Effects of $\mathrm{N}$ application rates on rice leaves anatomical structure at heading and flowering stage. (a) Photo of rice leaves; (b) paraffin sections of rice leaves $(20 \times)$; (c) paraffin sections of rice leaves $(40 \times)$.

Table 2. Effects of $\mathrm{N}$ application rates on morphological parameters of rice leaves.

\begin{tabular}{|c|c|c|c|c|}
\hline \multirow{2}{*}{ Treatment } & \multicolumn{3}{|c|}{ Small Vascular Bundle } & \multirow{2}{*}{$\begin{array}{l}\text { Alveolar Cell Area } \\
\qquad\left(10^{2} \mu \mathrm{m}^{2}\right)\end{array}$} \\
\hline & Number & Area $\left(10^{2} \mu \mathrm{m}^{2}\right)$ & Perimeter $\left(10^{2} \mu \mathrm{m}\right)$ & \\
\hline No & $17.7 \pm 0.6 \mathrm{~b}$ & $13.4 \pm 1.4 \mathrm{c}$ & $1.7 \pm 0.1 \mathrm{~b}$ & $16.1 \pm 0.7 \mathrm{~b}$ \\
\hline N90 & $18.3 \pm 0.6 \mathrm{ab}$ & $15.8 \pm 1.5 \mathrm{bc}$ & $1.6 \pm 0.1 \mathrm{~b}$ & $17.0 \pm 0.8 \mathrm{ab}$ \\
\hline N180 & $19.0 \pm 1.0 \mathrm{a}$ & $16.2 \pm 1.1 \mathrm{bc}$ & $1.9 \pm 0.2 \mathrm{ab}$ & $20.4 \pm 2.2 \mathrm{a}$ \\
\hline
\end{tabular}


Table 2. Cont.

\begin{tabular}{|c|c|c|c|c|}
\hline \multirow{2}{*}{ Treatment } & \multicolumn{3}{|c|}{ Small Vascular Bundle } & \multirow{2}{*}{$\begin{array}{l}\text { Alveolar Cell Area } \\
\qquad\left(10^{2} \mu \mathrm{m}^{2}\right)\end{array}$} \\
\hline & Number & Area $\left(10^{2} \mu \mathrm{m}^{2}\right)$ & Perimeter $\left(10^{2} \mu \mathrm{m}\right)$ & \\
\hline $\mathrm{N} 270$ & $19.3 \pm 0.6 \mathrm{a}$ & $19.2 \pm 2.8 \mathrm{ab}$ & $1.9 \pm 0.1 \mathrm{a}$ & $19.8 \pm 2.8 \mathrm{a}$ \\
\hline N360 & $19.3 \pm 0.6 \mathrm{a}$ & $19.7 \pm 2.1 \mathrm{a}$ & $2.0 \pm 0.2 \mathrm{a}$ & $18.6 \pm 2.4 \mathrm{ab}$ \\
\hline
\end{tabular}

Values followed by a different lower-case letter in the same vertical column were statistically different ( $p<0.05$; Duncan's test).

\subsection{Effects of $N$ Application Rates on N Contents of Rice Plants}

We investigated $\mathrm{N}$ content of rice leaves, stems and panicles under different $\mathrm{N}$ levels at tillering, jointing and booting, earing and flowering and harvest stages, as shown in Figure 4. N content in each organ of rice plants increased gradually with increasing $\mathrm{N}$ application rate. However, $\mathrm{N}$ content in rice leaves, stems and sheaths showed a gradual decreasing tendency during the whole growth period (Figure 4a,b). From the tillering stage to the heading and flowering stage, the order of total $\mathrm{N}$ content of each organ of rice plants was leaf $>$ stem and sheath $>$ spike. Compared with other treatments, the leaf $\mathrm{N}$ content of N360 treatment was increased by 60.45 to $134.89 \%$, the stem and sheath N content was increased by 26.62 to $68.83 \%$, and the spike $\mathrm{N}$ content was increased by 0.27 to $41.78 \%$ (Figure 4c). The above results suggested that the excessive $\mathrm{N}$ absorption by rice plants with high $\mathrm{N}$ treatments accumulated mainly in the leaves and stem sheaths, rather than transferring to grains. Consistent with the results of Yan et al., they used the ${ }^{15} \mathrm{~N}$ tracer method to study and found that when the nitrogen application amount was greater than $\mathrm{N}$ $200 \mathrm{~kg} / \mathrm{hm}^{2}, \mathrm{~N}$ accumulation did not increase in the grains but significantly increased in the stems and leaves [28].

\subsection{Effects of N Application Rates on Rice NUE and Yield}

As shown in Table 3, different $\mathrm{N}$ application rates have significant effects on the yield of double-cropping rice. Rice yield increased firstly and then decreased gradually with the increase in N application over N180 treatment. The N utilization rates of rice were the highest with $180 \mathrm{~kg} / \mathrm{hm}^{2}$ urea treatment, and yields of early rice and later rice were 17.42 to $33.28 \%$ and 6.17 to $21.28 \%$ higher than $\mathrm{N}$ fertilization treatments, respectively. Analyzing the components of rice yield, it was found that with the increase in $\mathrm{N}$ application rate, the order of effective panicle size per plant was N180 $>$ N270 $>$ N360 $>$ N90 $>$ N0. The results suggested that the application of $\mathrm{N}$ fertilizer mainly enhanced the effective panicle number of rice, but excessive $\mathrm{N}$ application would prolong the vegetative growth period of rice plants, and some of tillers were ineffective. The order of the seed setting rate of each treatment was N180 > N270 > N360 > N90 > N0. Among five treatments, N180 treatment had the highest seed setting rate, which were $83.66 \%$ for early rice and $83.90 \%$ for late rice. The reason for the phenomenon might be that low $\mathrm{N}$ treatment led to $\mathrm{N}$ deficiency in rice, decrease in tillers and, thus, the reduction in rice yields. While the application of excessive $\mathrm{N}$ fertilizer increased ineffective tillers, it made rice plants greedy green and late maturity and, thus, limited the increase in yield. Previous studies have shown that there was a parabolic relationship between $\mathrm{N}$ application rate and yield, and only the appropriate $\mathrm{N}$ dosage $\left(150-220 \mathrm{~kg} / \mathrm{hm}^{2}\right)$ could increase rice yield $[29,30]$. Our results further confirmed that the appropriate $\mathrm{N}$ dosage for ZCSM cultivar was N180 kg/hm², and NUE under N180 treatment was the highest, which were $43.47 \%$ for early rice and $44.63 \%$ for late rice. The results also suggested that high input of N fertilizer (N270 and N360) was not conducive to N absorption and utilization in both early rice and later rice. 
(a)

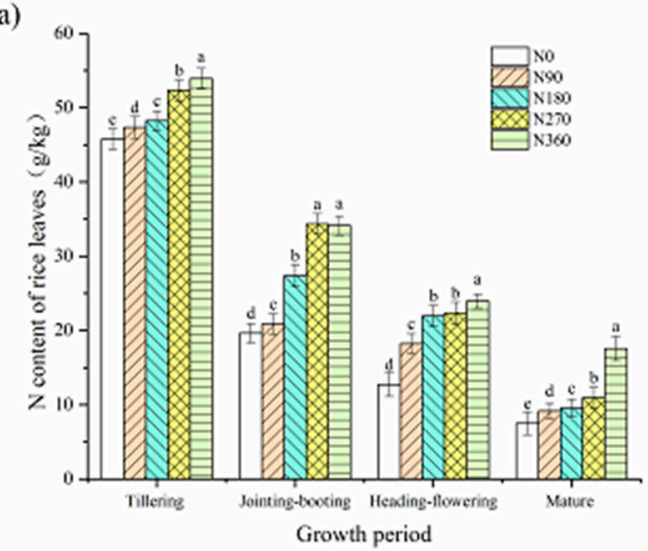

(c)

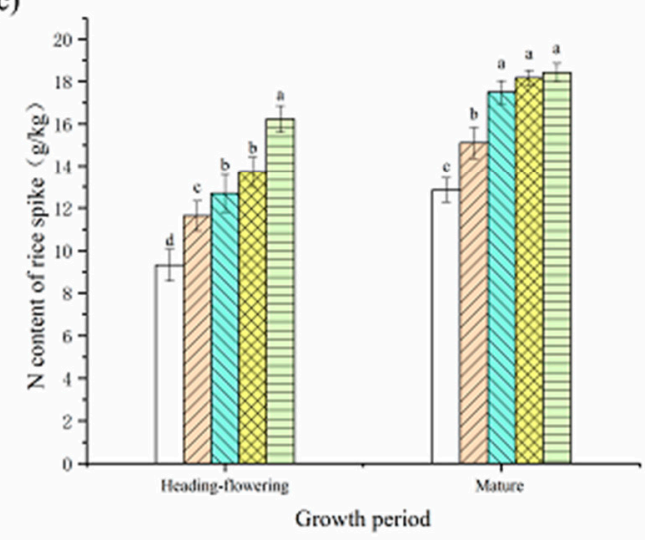

(b)

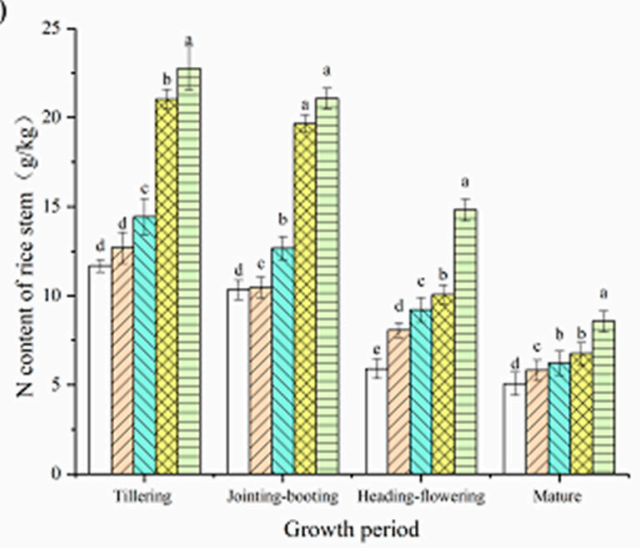

Figure 4. Effects of $\mathrm{N}$ application rates on $\mathrm{N}$ contents of rice plants. (a) $\mathrm{N}$ content of rice leaves; (b) $\mathrm{N}$ content of rice stem; (c) $\mathrm{N}$ content of rice spikes; vertical bars indicated the standard error. Different letters with the same growth period indicated significant differences at $p<0.05$ according to the Duncan's test. Tillering means tillering stage; jointing-booting means jointing-booting stage; heading-flowering means heading-flowering stage; mature means mature stage.

Table 3. Effect of N application rates on rice NUE and yield of double-cropping rice.

\begin{tabular}{|c|c|c|c|c|c|c|c|c|}
\hline Year & Rice & Treatment & $\begin{array}{l}\text { Spike Per } \\
\text { Plant }\end{array}$ & $\begin{array}{l}\text { Efficient } \\
\text { Spike Per } \\
\text { Plant }\end{array}$ & $\begin{array}{c}\text { Setting } \\
\text { Percentage (\%) }\end{array}$ & $\begin{array}{c}\text { Thousand } \\
\text { Seed Weight } \\
\text { (g) }\end{array}$ & $\begin{array}{l}\text { Yield } \\
\text { (g/pot) }\end{array}$ & $\begin{array}{c}\text { NUE } \\
(\%)\end{array}$ \\
\hline \multirow{10}{*}{2020} & \multirow{5}{*}{ Early rice } & No & $4.0 \pm 0.0 \mathrm{c}$ & $4.0 \pm 0.0 \mathrm{c}$ & $81.7 \pm 0.7 b$ & $16.4 \pm 0.8 \mathrm{ab}$ & $6.6 \pm 0.9 \mathrm{~d}$ & - \\
\hline & & N90 & $4.7 \pm 0.6 \mathrm{~b}$ & $4.7 \pm 0.6 \mathrm{c}$ & $82.7 \pm 0.4 \mathrm{ab}$ & $17.5 \pm 0.4 \mathrm{a}$ & $12.5 \pm 0.7 \mathrm{c}$ & 41.74 \\
\hline & & N180 & $7.3 \pm 0.6 \mathrm{a}$ & $7.3 \pm 0.6 \mathrm{a}$ & $83.7 \pm 0.6 \mathrm{a}$ & $17.3 \pm 0.26 \mathrm{a}$ & $17.0 \pm 0.9 \mathrm{a}$ & 43.47 \\
\hline & & N270 & $8.0 \pm 0.0 \mathrm{a}$ & $6.7 \pm 0.6 \mathrm{ab}$ & $83.1 \pm 0.7 \mathrm{a}$ & $15.3 \pm 0.9 \mathrm{bc}$ & $14.5 \pm 0.2 \mathrm{~b}$ & 39.59 \\
\hline & & N360 & $8.0 \pm 0.0 \mathrm{a}$ & $6.3 \pm 0.6 b$ & $81.6 \pm 1.0 \mathrm{~b}$ & $14.8 \pm 0.4 \mathrm{c}$ & $12.3 \pm 0.6 \mathrm{c}$ & 36.10 \\
\hline & \multirow{5}{*}{ Late rice } & No & $4.7 \pm 0.6 \mathrm{~b}$ & $4.7 \pm 0.0 \mathrm{c}$ & $81.4 \pm 0.7 \mathrm{~d}$ & $16.3 \pm 0.7 b$ & $6.9 \pm 0.8 \mathrm{~d}$ & - \\
\hline & & N90 & $5.3 \pm 0.6 b$ & $5.3 \pm 0.6 c$ & $82.9 \pm 0.7 b c$ & $17.7 \pm 0.3 \mathrm{a}$ & $14.5 \pm 0.2 \mathrm{c}$ & 41.25 \\
\hline & & N180 & $8.0 \pm 0.0 \mathrm{a}$ & $8.0 \pm 0.0 \mathrm{a}$ & $83.9 \pm 0.5 \mathrm{a}$ & $18.1 \pm 0.1 \mathrm{a}$ & $18.9 \pm 0.5 \mathrm{a}$ & 44.63 \\
\hline & & N270 & $8.3 \pm 0.6 \mathrm{a}$ & $7.7 \pm 0.6 \mathrm{a}$ & $83.3 \pm 0.4 \mathrm{ab}$ & $16.0 \pm 0.8 \mathrm{bc}$ & $16.0 \pm 0.7 b$ & 40.14 \\
\hline & & N360 & $8.3 \pm 0.6 \mathrm{a}$ & $6.7 \pm 0.6 b$ & $82.1 \pm 0.8 \mathrm{~cd}$ & $15.2 \pm 0.3 c$ & $14.7 \pm 0.4 \mathrm{c}$ & 36.54 \\
\hline
\end{tabular}

Values followed by a different lower-case letter in the same vertical column were statistically different ( $p<0.05$; Duncan's test). Early rice and late rice were compared separately.

\section{Conclusions}

The application of urea and ammonium sulfate in double-cropping rice at the heading and flowering stage could improve the nitrogen content and photosynthetic capacity of rice leaves and increase rice yield and efficient utilization of nitrogen fertilizer. Urea $\mathrm{N}$ application rate of $180 \mathrm{~kg} / \mathrm{hm}^{2}$ could improve $\mathrm{N}$ utilization rate of plants (stem sheath, leaf 
and ear) significantly, enable functional leaves of rice to have strong light capture ability and photochemical efficiency during the heading and flowering period and, thus, promote rice yield increase in comparison to other urea treatments. According to the comprehensive effects of $\mathrm{N}$ absorption, photosynthetic characteristics and yield of rice, the best form and application rate of $\mathrm{N}$ fertilizer was urea $\left(180 \mathrm{~kg} / \mathrm{hm}^{2}\right)$ as base fertilizer, tiller fertilizer and spike fertilizer at the ratio of 4:4:2, which could be used as the best nitrogen application mode under the double-cropping mode of rice planting in South China.

Author Contributions: H.S. initiated and designed the research, H.F. and D.C. performed the experiments, H.F. analyzed the data and wrote the manuscript, H.S. revised and edited the manuscript and also provided advice on the experiments. All authors have read and agreed to the published version of the manuscript.

Funding: This work was supported by the Research and Development Program in Key Areas of Guangdong Province, China (grant number 2019B020214002) and the Science and Technology Planning Project of Guangdong, (grant number 2019B030301007).

Institutional Review Board Statement: Not applicable.

Informed Consent Statement: Not applicable.

Data Availability Statement: Data sharing not applicable.

Acknowledgments: We thank to Xujian Yang, Jin Yang, Weiguang Yang, Shuo Ma, Wenkang Chen, Yuhao Tian and Chaoxin Wang for their valuable help.

Conflicts of Interest: The authors declare no conflict of interest.

\section{References}

1. Wang, X.; Jiang, Y.; Liu, Y.; Lu, J.; Yin, X.; Shi, L.; Huang, J.; Chu, Q.; Chen, F. Spatio-temporal changes of rice production in china based on county unit. Acta Agron. Sin. 2018, 44, 1704-1712. [CrossRef]

2. Nie, J.; Yi, L.; Xu, H.; Liu, Z.; Zeng, Z.; Dijkstra, P.; Koch, G.W.; Hungate, B.A.; Zhu, B. Leguminous cover crop astragalus sinicus enhances grain yields and nitrogen use efficiency through increased tillering in an intensive Double-Cropping rice system in southern china. Agronomy 2019, 9, 554. [CrossRef]

3. Jin, H.; Fu, L.; Hao, N.; Gao, W.; Wu, Z. Effects of Different Nitrogen Levels on Plant Types and Yields of 4 Japonica Rice Varieties. Mol. Plant Breed. 2018, 16, 670-677.

4. Qaswar, M.; Huang, J.; Ahmed, W.; Liu, S.; Li, D.; Zhang, L.; Liu, L.; Xu, Y.; Han, T.; Du, J.; et al. Substitution of inorganic nitrogen fertilizer with green manure (GM) increased yield stability by improving c input and nitrogen recovery efficiency in rice based cropping system. Agronomy 2019, 9, 609. [CrossRef]

5. Song, X.; Liu, K.; Peng, B.; Duan, B.; Li, J.; He, S.; Li, H.; Zhang, S.; Wang, K.; Hu, Y.; et al. Effects of nitrogen application rate on population quality and yield of japonica hybrid rice in southern henan. Hybrid Rice 2019, 34, 39-43.

6. Zhang, W. Effects of Different Nitrogen Application Rates and Densities on Yield and Population Structure of Yongyou 1540. China Rice 2020, 26, 91-93.

7. Yin, X.; Li, C. Differences in leaf photosynthesis and assimilation of nitrogen between two rice cultivars differing in nitrogen use efficiency. Crops 2019, 35, 90-96.

8. Duan, Y.; Zhang, Y.; Wang, S.; Shen, Q. Effect of $\mathrm{NH}^{4+}$ to $\mathrm{NO}^{3-}$ ratio $\left(\mathrm{NH}^{4+} / \mathrm{NO}^{3-}\right)$ on biological characteristics of rice with different nitrogen use efficiency. J. Nanjing Agric. Univ. 2007, 30, 73-77.

9. Ma, S.; Chen, W.; Zhang, J.; Hong, H. Influence of simulated acid rain on the physiological response of flowering Chinese cabbage and variation of soil nutrients. Plant Soil Environ. 2020, 66, 648-657. [CrossRef]

10. Meier, U. Growth Stages of Mono and Dicotyledonous Plants. BBCH Monograph; Federal Biological Research Centre for Agriculture and Forestry: Bonn, Germany, 2001.

11. Yang, L.; Zhang, Y.; Yang, L.; Xie, J.; Yang, M.; Zhang, Y.; Shi, X. Effects of different nitrogen and potassium rates on dry matter accumulation, transport and yield of rice. Soils Fertil. Sci. China 2019, 4, 89-95.

12. Yang, H.; Li, J.; Yang, J.; Wang, H.; Zou, J.; He, J. Effects of nitrogen application rate and leaf age on the distribution pattern of leaf SPAD readings in the rice canopy. PLoS ONE 2014, 9, e88421. [CrossRef] [PubMed]

13. Zhen, B.; Guo, X.; Lu, H. Effects of alternative stress of drought and waterlogging at tillering stage on rice root anatomical structure. Trans. Chin. Soc. Agric. Eng. 2015, 31, 107-113.

14. Chen, G.; Zhou, Y.; Guo, S.; Shen, Q. The regulatory mechanism of different nitrogen form on photosynthetic efficiency of rice plants under water stress. Sci. Agric. Sin. 2007, 10, 2162-2168.

15. Li, S.; Shi, W. Effect of Nitrogen form on Root Morphology and Nitrogen Absorption Efficiency of two Cultivars of Rice. Soils 2007, 39, 589-593. 
16. Juan, Y.; Chen, L.; Wu, Z.; Zhou, L.; Wang, R. Thermodynamic characteristics of soil urease under influence of inhibitors and temperature. J. Liaoning Tech. Univ. Nat. Sci. 2010, 29, 1149-1152.

17. Chen, X.; Jiang, Z.; Ding, J.; Cai, M.; Yang, S. Impacts of biochar application on soil nitrogen content and urease activity in water-saving irrigation paddy fields. Jiangsu Agric. Sci. 2020, 48, 268-274.

18. Guarini, J.M.; Moritz, C. Modelling the dynamics of the electron transport rate measured by PAM fluorimetry during Rapid Light Curve experiments. Photosynthetica 2009, 47, 206-214. [CrossRef]

19. Xu, C.; Liu, X.; Li, Q.; Ling, F.; Wu, Z.; Zhang, Z. Effect of salt stress on photosynthesis and chlorophyll fluorescence characteristics of rice leaf for nitrogen levels. Chin. Bull. Bot. 2018, 53, 185-195.

20. Zhao, X.; Chen, T.; Feng, B.; Zhang, C.; Peng, S.; Zhang, X.; Fu, G.; Tao, L. Non-photochemical quenching plays a key role in light acclimation of rice plants differing in leaf color. Front. Plant Sci. 2017, 7, 1968. [CrossRef]

21. Liu, X.; Xu, C.; Ji, P.; Li, Q.; Yang, H.; Wu, Z.; Wang, H. Correlation between the chlorophyll fluorescence characteristics of leaf and ions accumulation in rice under salt stress. Mol. Plant Breed. 2020, 3, 1-15.

22. Zhang, Z.; Zheng, E.; Wang, Z.; Yuan, N. Effect of different water and nitrogen levels on chlorophyll fluorescence parameters and photosynthetic characteristics of rice. Trans. Chin. Soc. Agric. Mach. 2017, 48, 176-183.

23. Li, G.; Ding, Y.; Xue, L.; Wang, S. Research progress on diagnosis of nitrogen nutrition and fertilization recommendation for rice by use chlorophyll meter. Plant Nutr. Fertil. Sci. 2005, 11, 412-416.

24. Hou, Y.; Han, L.; Kong, L.; Yin, C.; Qin, Y.; Li, Q.; Xie, J. Nutrient absorption, translocation in rice and soil nitrogen equilibrium under different nitrogen application doses. J. Plant Nutr. Fertil. 2015, 21, 836-845.

25. Xiong, D.; Liu, X.; Liu, L.; Douthe, C.; Li, Y.; Peng, S.; Huang, J. Rapid responses of mesophyll conductance to changes of $\mathrm{CO} 2$ concentration, temperature and irradiance are affected by $\mathrm{N}$ supplements in rice. Plant Cell Environ. 2015, 38, 2541-2550. [CrossRef] [PubMed]

26. Li, F.; Bao, W. Responses of the morphological and anatomical structure of the plant leaf to environmental change. Chin. Bull. Bot. 2005, 22, 118-127.

27. Lu, H.; Guo, X.; Zhen, B.; Qiao, D.; Zhou, X.; Wang, Z.; Liu, C.; Yang, B. Effects of alternative stress of drought and waterlogging on rice leaf anatomical structure at tillering stage. Trans. Chin. Soc. Agric. Eng. 2017, 33, 116-122.

28. Yan, J.; Yin, B.; Zhang, S.; Shen, Q.; Zhu, Z. Effect of nitrogen application rate on nitrogen uptake and distribution in rice. J. Plant Nutr. Fertil. 2008, 14, 835-839.

29. Li, J.; Feng, Y.; Wang, X.; Ma, J.; Wu, Y.; Li, X.; Ye, Y.; Huang, Y.; Mou, G. Analysis of SPAD Value of Rice Leaf and Yield Under Different Soil Fertility and Nitrogen Application. China Rice. 2017, 23, 26-30.

30. Wang, W.; Lu, J.; He, Y.; Li, X.; Li, H. Effects of n, p, k fertilizer application on grain yield, quality, nutrient uptake and utilization of rice. Chin. J. Rice Sci. 2011, 25, 645-653. 